\title{
Becoming an American Citizen
}

\begin{tabular}{|c|c|}
\hline SuDoc & Title \\
\hline HS 8.19:H 62/DVD & A promise of freedom \\
\hline HS 8.2:C 49/2/2009/TOOLKIT & Civics and citizenship toolkit \\
\hline HS 8.2:F 61/2/2017 & Civics flash cards for the new naturalization test \\
\hline HS 8.2:F 61/2/2017/Span. & Tarjetas de educación cívica para el examen de naturalizacíon \\
\hline HS 8.2:F 61/3/2016 & Vocabulary flash cards for the naturalization test \\
\hline HS 8.2:L 47/2017 & Learn about the United States \\
\hline HS 8.2:T 28/2017 & The naturalization test, overview of requirements and available resources \\
\hline HS 8.24:2017 & Preparing for the naturalization test, a pocket study guide \\
\hline J 21.2:En 3/2 & $\begin{array}{l}\text { By the people--U.S. government structure, an English as a second language } \\
\text { text }\end{array}$ \\
\hline $\mathrm{J} 21.2:$ EN $3 / 3$ & $\begin{array}{l}\text { Of the people--U.S. government structure, an English as a second language } \\
\text { text }\end{array}$ \\
\hline J $21.2: \operatorname{lm} 6 / 3 / 963$ & Our immigration, a brief account of immigration to the United States \\
\hline $\mathrm{J} 21.2: \mathrm{R} 31 / 2$ & Retiring to a new beginning \\
\hline J 21.6/3:C 49/979 & Gateway to citizenship \\
\hline J 21.6/3:N 21 & Basic guide to naturalization \\
\hline J 21.6/3:N 21/3/2000 & A guide to naturalization \\
\hline J 21.6/3:N 21/3/CHIN. & A guide to naturalization \\
\hline J 21.6/3:N 21/3/SPAN. & A guide to naturalization \\
\hline J 21.6/3:N 21/3/VIET. & A guide to naturalization \\
\hline J 21.9:C 49/4/BK.1 & Becoming a citizen series. Book 1, our American way of life \\
\hline J 21.9:C 49/5 & A welcome to U.S.A. citizenship \\
\hline J 21.9:R 44/963 & Rights of the people \\
\hline Y 4.J 89/1:105/36 & Safeguarding the integrity of the naturalization proces \\
\hline Y 4.J 89/1:110-64 & Naturalization delays: causes, consequences, and solutions \\
\hline Y 4.J 89/2:Im 6/6 & History of the Immigration and Naturalization Service \\
\hline Y 4.J 89/2:S.hrg.101-741 & Naturalization procedures \\
\hline
\end{tabular}

